\title{
The Impact of Learning Model Based on 2013 Curriculum Towards Contextual Problem Solving Skill
}

\author{
Sehatta Saragih ${ }^{1}$, Zulkarnain $^{2}$, Sahrun Nisa $^{3}$ \\ \{sehattasaragih@lecturer.unri.ac.id ${ }^{1}$; zulkarnain@lecturer.unri.ac.id²; sahrun@upi.edu ${ }^{3}$ \} \\ FKIP, Univeristas Riau, Kampus Bina Widya KM 12,5 Pekanbaru ${ }^{1,2}$, Sekolah Pascasarjana, \\ Universitas Pendidikan Indonesia, Jalan Setiabudi, Bandung ${ }^{3}$
}

\begin{abstract}
This study is sat out from reinforcement of scientific approach as 21 st century learning. Therefore, learning management that recommended to use is Project based learning that using contextual problem as learning resource material. In line with this idea, the purpose of this study is to examine the competence of Grade VII students in solving contextual questions that consider one of the vehicles for building HOTS abilities. The subjects of this study were students of class VII Tp. 2019/2020 arrested 356 people. Research data were collected by tests then analyzed descriptively and inferentially. The results of data analysis showed that: (1) students who were taught with K13-based learning models had significantly better ability to solve problems compared to students who were taught conventionally; (2) the ability of students who are taught using K13-based learning models in solving contextual questions is better than students who are taught in the conventional way at each level.
\end{abstract}

Keywords: Learning Model Based on 2013 Curriculum, Contextual Problem.

\section{Introduction}

Implementation of Curriculum 2013 (K13) is used to support 21st century learning in order to respond the demands of an increasingly competitive era and reflect the critical thinking and problem solving, creativity and innovation, communication, and also collaboration. Therefore, optimizing the implementation of K13 is seen as a starting point for the success of 21 st century learning. In this connection, efforts to strengthen the implementation of K13 continue to be carried out by integrating into appropriate learning models.

Speaking of mathematical thinking and problem solving abilities, TIMSS (2015) [1] sliced the ability of Indonesian children in mathematics to be ranked 44th out of 49 countries with a score of 397 with an average overall score of 500. Whereas the 2015 PISA report, a similar issue where out of the 72 countries that participated in this evaluation Indonesia ranked 64th with an average of 386, Tohir (2016) [2]. This achievement, shows that the ability of thinking and mathematical understanding of Indonesian students is still low.

Fakta ini dapat dijadikan salah satu indikator yang menunjukkan bahwa kualitas pengelolaan pembelajaran matematik perlu ditingkatkan. Banyak pakar merespon hal ini dengan mengatakan, pengelolaan pembelajaran mekanistik yang lebih menekankan pada hasil dibandingkan proses berpikir dipandang sebagai salah satu factor penyebabnya. Sejalan dengan pernyataan ini, Suryadi (2005)3 dan Hudojo (2002)4 mengungkapkan bahwa sebagian besar 
kegiatan pembelajaran matematika belum berfokus pada pengembangan penalaran matematik atau kemampuan berpikir logis siswa.

This fact can be used as one indicator that shows the quality of the management of mathematical learning needs to be improved. Many experts respond to this by saying, the management of mechanistic learning that emphasizes more on results than the thought process is seen as one of the contributing factors. In line with this statement, Suryadi [3] and Hudojo [4] revealed that most mathematics learning activities have not focused on developing mathematical reasoning or students' logical thinking abilities.

Aware of the learning conditions, the presence of K13 which carries a scientific approach as learning innovation is seen as able to overcome the problem. By emphasizing the active role of students in developing their knowledge through the process of scientific thinking that is characterized by learning activities to observe, ask questions, gather information, reason, and communicate believed to be able to provide different colors of learning to improve students' thinking abilities.

Recommend K13 that the implementation of the scientific approach into the project-based learning model (Project Based Learning / PjBL) is seen as an effort to improve the quality of learning in an effort to improve students' reasoning and mathematical abilities. In connection with this effort, the impact of learning on the ability of high order mathematical thinking (HOTS) is interesting to study comprehensively. The habit of giving contextual questions can be used as a vehicle to build thinking ability and mathematical reasoning. The problem is how much the learning model contributes to students' ability to solve problems contextual matters.

\section{Theoterical Framework}

The implementation of the 2013 curriculum is expected to strengthen 21 st century learning that reflects four things namely critical thinking and problem solving, creativity and innovation, communication, also collaboration. To realize learning with these four pillars, a learning approach is needed that can facilitate these learning activities. The learning approach can be seen as a series of learning actions based on certain basic principles (philosophical, psychological, didactic and ecological) that embody, inspire, strengthen and underlie certain learning methods [5]

Contructivism holds that learning means experiencing and building knowledge actively. This shows that the learning process can be paired with a scientific process, which refers to investigative techniques for one or several phenomena or symptoms, gaining new knowledge, or correcting and integrating prior knowledge. To be called scientific, the method of inquiry (method of inquiry) must be based on evidence from observable, empirical, and measurable objects with specific principles of reasoning. Therefore, scientific methods generally contain a series of data collection activities through observation or experimentation, processing information or data, analyzing, then formulating, and testing hypotheses. The 2013 curriculum mandates the essence of a scientific or scientific approach in the management of learning.

Learning with a scientific approach is a learning process that is designed so that students actively construct concepts, laws or principles of the five stages of learning namely observing, asking, gathering information, reasoning and communicating. The scientific approach provides understanding to students in building information learning experiences from various sources not only from the teacher. Therefore the conditions of learning are directed to encourage students to find out from various sources through observation, and not just to be told. It is believed that 
the process of building a new learning experience, will be more meaningful if it is based on the experience that already has.

Looking at the learning activities required in a scientific approach it is important to package this approach into a learning model. Speaking of learning models, can be interpreted as a conceptual framework in developing learning plans, then each learning model has a different way of planning its packaging.

Since the learning process is a major factor influencing learning outcomes, it cannot be denied that good learning planning greatly contributes to the quality of the learning process and its results. In the National Council of Teachers of Mathematics [6] states that the learning process factor occupies the first position that affects learning outcomes besides innate abilities. This indicates that proper planning is one of the keys to creating quality learning. Thus it is no exaggeration to say the ability to deliver material is the first condition, and the ability to master the material is the second key requirement for success in managing learning.

Related to the learning model as an subset in the implementation of the scientific approach, in K13 it is recommended to use a project-based learning model (Project Based Learning / PjBL) Project-based learning is a learning model that uses projects / activities as the core of learning. Students carry out exploration, assessment, interpretation, synthesis, and information to produce various forms of learning outcomes both cognitive and affective. Utilization of students' real problems at the beginning of learning as a vehicle to build knowledge makes students aware that learning is a life activity. This condition will trigger students' curiosity, thus encouraging intrinsic motivation to deepen things learned.

There are several mathematical learning models that are in line with PjBL, namely RME, PBL, CTL, Discovery, REACT, LQ5E and others. The problem is the material which is suitable to be learned with certain learning models and approaches. This is considering that certain materials are only suitable to be delivered with certain models. In other words not all material is suitable to be delivered with one model, and not all approaches or learning models are suitable to be used to address certain material.

There are several things that can be considered in choosing a learning model, including:

1. The suitability of the learning model with attitude competencies in main competence (MC) 1 and MC-3 as well as knowledge and skills competencies in accordance with Basic Competence (BC)-3 and / or BC-4.

2. The suitability of the learning model with the characteristics of BC-1 (if any) and BC2 that can develop attitude competencies, and the suitability of learning material with the demands of BC-3 and BC-4 to develop knowledge and skills competencies.

3. The use of a scientific approach that develops students' learning experiences through an activity known as 5M [7]

As stated at the begining, that the use of project-based learning is intended as a vehicle for students to build mathematical understanding, reasoning, communication and problem solving by accustoming students to solving contextual mathematical problems.

Talking about questions or contextual problems, then we first understand the meaning / meaning of contextual words. Contextual words in Oxford Dictionary [8] are interpreted as situational, social, and / or interpersonal factors in the interpretation of messages or actions. Furthermore, in the use of linguistics, contextual words usually refer to extralinguistic factors (such as the context of the situation). In KBBI contextual word is interpreted as citation which has to do with an event. For example someone who is whole in the context of personal and community life.

Based on the opinion above, contextual words can be interpreted as situational factors in the form of messages or actions. The word situational relates to conditions experienced (ever 
experienced) both in the form of information or events experienced (actions). Furthermore, a problem can be said to be contextual if the problem situation can be experimentally experimented by students. [9] by paying attention to the context and meaning of contextual as well as the understanding of contextual problems as stated above, contextual problems in mathematics can be interpreted as mathematical problems that utilize or use problem situations that are either information or experienced by students (which are actually experimented by students).

According to de Lange [10] there are four kinds of context or situation problems, namely:

1) Student Personal. Situations relating to the daily lives of students both at home with family, with peers, classmates and pleasure.

2) School / Academic. Situations relating to academic life at school, in the classroom, and activities related to the learning process.

3) Community / Public. Situation related to the life and activities of the surrounding community where the student lives.

4) Scientific / Mathematical. Situations relating to phenomena and substances scientifically or related to mathematics itself.

Departing from the understanding of the contextual questions referred to in this research, in developing the instrument the researcher divided them up into three levels based on the complexity of the relations between concepts / principles contained in the question. Level one is a contextual problem that contains a relation between mathematical concepts or principles, and so on level two and level three.

\section{Research Method}

The type of this research is quasi-experiment because researcher cant not control all of aspect that can influence the research. Research design that used can be seen on Table 1 .

Tabel 1. Design of Reserch.

\begin{tabular}{lcc}
\hline Category & treatment & Posttest \\
\hline experiment & $\mathrm{X}_{1}$ & $\mathrm{O}$ \\
control & $\mathrm{X}_{2}$ & $\mathrm{O}$ \\
\hline
\end{tabular}

Note: $\quad \mathrm{X}_{1}$ : Learning Model Based on 2013 Curriculum

$\mathrm{X}_{2}$ : Conventional

The subjects of this study were students of class VII consisting of 9 classes divided into 5 experimental classes and 4 control classes. Data collection instruments are tests of ability to solve contextual questions that contain three levels of problem complexity. The data collected was then analyzed with inferential statistics to see the significance of the impact of the treatment given and descriptive to describe the ability of students to solve contextual questions. 


\section{Result and Discussion}

Starting the description of the results of this study, a brief description of the implementation of the research will be described. As stated, the implementation of the scientific approach in the project-based learning model (Project Based Learning / PjBL). In connection with that, in this study the selected learning models are PBL, RME, CTL, Discovery, REACT, LQ5E. This research was carried out for 16 sessions by applying all the learning models above that were adjusted to the characteristics of the material presented. Therefore, there are variations in the frequency of implementation of the learning model during research activities.

Furthermore, based on data calculations obtained images of students' ability to solve contextual questions both overall and based on the level of complexity of the questions, as illustrated on Figure 1.

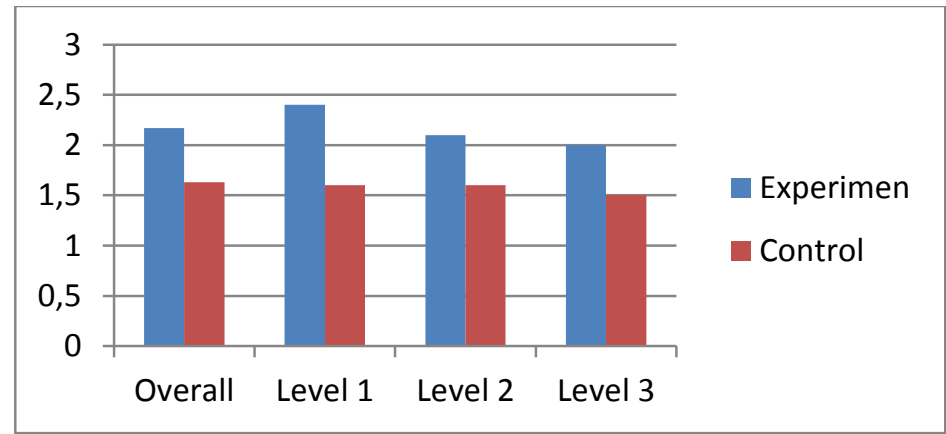

Fig. 1. Contextual problem solving ability description.

Based on the data contained in the diagram above, information is obtained that the application of the project-based learning model contributes better to students' ability to solve contextual questions, both in terms of overall and by level. This fact reinforces the argument that project-based learning models can be used as alternative learning strategies to build mathematical thinking skills.

Furthermore, when viewed from the average ability of students to solve contextual questions based on the level of questions students who are given treatment have a better ability to solve contextual questions. In this connection, it is necessary to look at the significance of these contributions by using the two difference test. The summary of the mean difference test results is contained in Table-1. Result of Double means difference description can be seen in Table 2.

Table.2 Result of Double means difference description.

\begin{tabular}{lcccccccc}
\hline Source & Control & Exp & \multicolumn{3}{c}{ Homogeny } & \multicolumn{3}{c}{ Mean test } \\
& & & $\mathbf{F}_{\mathbf{h}}$ & $\mathbf{F}_{\mathbf{t}(\mathbf{0 . 0 1})}$ & $\mathbf{K e s . H}_{\mathbf{0}}$ & $\mathbf{t}_{\mathbf{h}}$ & $\mathbf{t}_{\mathbf{t}(\mathbf{0 . 0 5})}$ & ${\text { Kes. } \mathbf{H}_{\mathbf{0}}}$ \\
\hline $\mathbf{N}$ & 145 & 211 & & & & & & \\
Mean & 1.33 & 2.16 & 1,15 & 4,47 & Retain & 7.87 & 1,32 & Reject \\
STDV & 0.08 & 0.06 & & & & & & \\
\hline
\end{tabular}

Note : ideal score is 3

From the facts Table 1 obtained information that the results of the average difference test of two samples of Ho were rejected. By paying attention to the average score of the ability to 
solve contextual questions of the two sample groups, it can be said that the application of the project-based learning model has a significantly better impact on students' ability to solve contextual questions. In general, contextual questions are non-routine problems that are identical to mathematical problems, so it can be generalized that project-based learning models significantly impact the ability to solve mathematical problems. The results of this study are in line with the results of previous studies namely: Chiang and [11] PBL has a positive impact on learning motivation and problem solving ability in students. Students who learn to use PBL can be facilitated to understand real world problems so students can solve real-world problems

The existence of these significant contributions and understanding the importance of habituating students to solve contextual questions is in line with the principles of 21 st century learning that project-based learning is used as a vehicle to build Critical Thinking and Problem Solving, Creativity and Innovation, Communication, Collaboration. Understanding the characteristics of the contextual problem solving process, where students are encouraged to reflect back concepts, principles and relationships between concepts / principles that have been built to perform algorithms to make student learning more meaningful. Such conditions allow students to restructure concepts and principles that they have with what they have just learned so that the new knowledge obtained is well structured and more meaningful so that it can be easily and quickly recalled if needed. Similar research results [12] through contextual mathematical problem solving, the subject will be trained to always involve his metachogical abilities starting from the beginning of problem solving to the end of the formulation of answers and evaluating to ensure the achievement of objectives related to the contextual situation of the problem solved.

Contextual problem solving also gives students the opportunity to organize their thought processes in choosing and establishing mathematical concepts and principles needed to solve the questions given. This condition has the opportunity to build the ability to identify the relationships between more specific mathematical objects, thereby strengthening the ability of better reasoning. Understanding this and the results of the study as described above, it can be said that project-based learning has the potential to build good reasoning skills.

The first step in completing a contextual problem is to establish mathematical communication in the form of a mathematical model from the given context. In this regard, and taking into account the results of the research that has been described, it can be stated that students who are taught with a project-based learning model have a better chance of building their communication skills. Besides that, if seen from the complexity of contextual questions at level three, which in solving them requires quite high communication skills, fact funds indicate that the ability of the treatment group students is better, indicating that the Project Based Learning (PjBL) learning model provides space for students to develop their communication skills

\section{Conclusion}

Based on data analysis and discussion, it can be concluded that: (1) students who are taught with the K13-based learning model have significantly better ability to solve contestants than students who are taught conventionally; (2) the ability of students who are taught using K13based learning models in solving contextual questions is better at each level compared to students who are taught conventionally 


\section{Recomendation}

Noting the results of research and discussion, in order to strengthen the implementation of 21st century learning, the application of Project Based Learning (PjBL) learning must be a priority learning strategy in order to improve students' mathematical thinking abilities. In this connection, several things are suggested, namely:

1. Related to the management of learning, providing space for students to try to collaborate with their peers to work cooperatively. This is intended so that students are accustomed to exchanging ideas with their peers in order to broaden students' thinking insights.

2. Regarding the test instrument, it is recommended that the complexity of the test be increased to four levels. It aims to see further the impact of students' thinking abilities so that they can describe the differences more significantly.

\section{References}

[1] Parhusip, (2016) Bagaimana Pendidikan Matematika Indonesia dengan Program for Internasional Student Assessment (PISA) dan Treds in Internasional Mathenatics and Science Study (TIMSS). https://www.researchgate/publication. Diakses pada tanggal 21 Agustus 2019.

[2] Tohir, Muhammad (2016), Hasil PISA Indonesia Tahun 2015 Mengalami Peningkatan. Paper. 10. $1-2$

[3] Suryadi, D. (2005). Penggunaan Pendekatan Pembelajaran Tidak Langsung serta Pendekatan Gabungan Langsung dan Tidak Langsung dalam Rangka Meningkatkan Kemampuan Matematik Tingkat Tinggi Siswa SLTP. Disertasi Doktor pada PPS UPI: Tidak Diterbitkan.

[4] Hudoyo, H. (2002). Representasi Belajar Berbasis Masalah. Jurnal Matematika atau Pembelajarannya. (Edisi Khusus), 427- 432.

[5] Kementerian Pendidikan dan Kebudayaan (2013) Kerangka Dasar Dan Struktur Kurikulum Sekolah Menengah Kejuruan /Madrasah Aliyah Kejuruan, Jakarta.

[6] National Council of Teacher of Mathematics. (2000). Principles and Standards for School Mathematics. Reston, VA: NCTM.

[7] Sufairoh, 2016. Pendekatan Saintifik \& Model Pembelajaran K-13, Jurnal Pendidikan Profesional, Volume 5, No. 3, Desember 2016

[8] Oxford reference. (2019). https://www.oxfordreference.com/view/ 10.1093 /oi/authority. 2011080 3095634891. Diakses pada tanggal 21 Agustus 2019.

[9] Gravemeijer, K. \& Doorman. (1999), Context Problems in Realistic Mathematics Education:A calculus course as an example,39(1),111-129, Retrieved on 12th July 2014,http://www.jstor.org/stable/3483163.

[10] Suherman. (2015). Kreativitas Siswa Dalam Memecahkan Masalah Matematika Materi Pola Bilangan dengan Pendekatan Matematika Realistik (PMR). Al-Jabar : Jurnal Pendidikan Matematika. 6 (1). $81-90$

[11] Chiang, C.L. and H. Lee. (2016). The Effect of Project-Based Learning on Learning Motivation and Problem-Solving Ability of Vocational High School Students. International Journal of Information and Education Technology. 6(9). 709-712. DOI: 10.7763/IJIET.2016.V6.779

[12] Anggo (2011) Pemecahan Masalah Matematika Kontekstual Untuk Meningkatkan Kemampuan Metakognisi Siswa. Edumatica. 1 (2). Halaman 35-42 